\title{
Scoping Corrosion Tests on Candidate Waste Package Basket Materials for the Yucca Mountain Project
}

\author{
R.A. Van Konynenburg \\ P.G. Curtis \\ T.S.E. Summers
}

March 1998

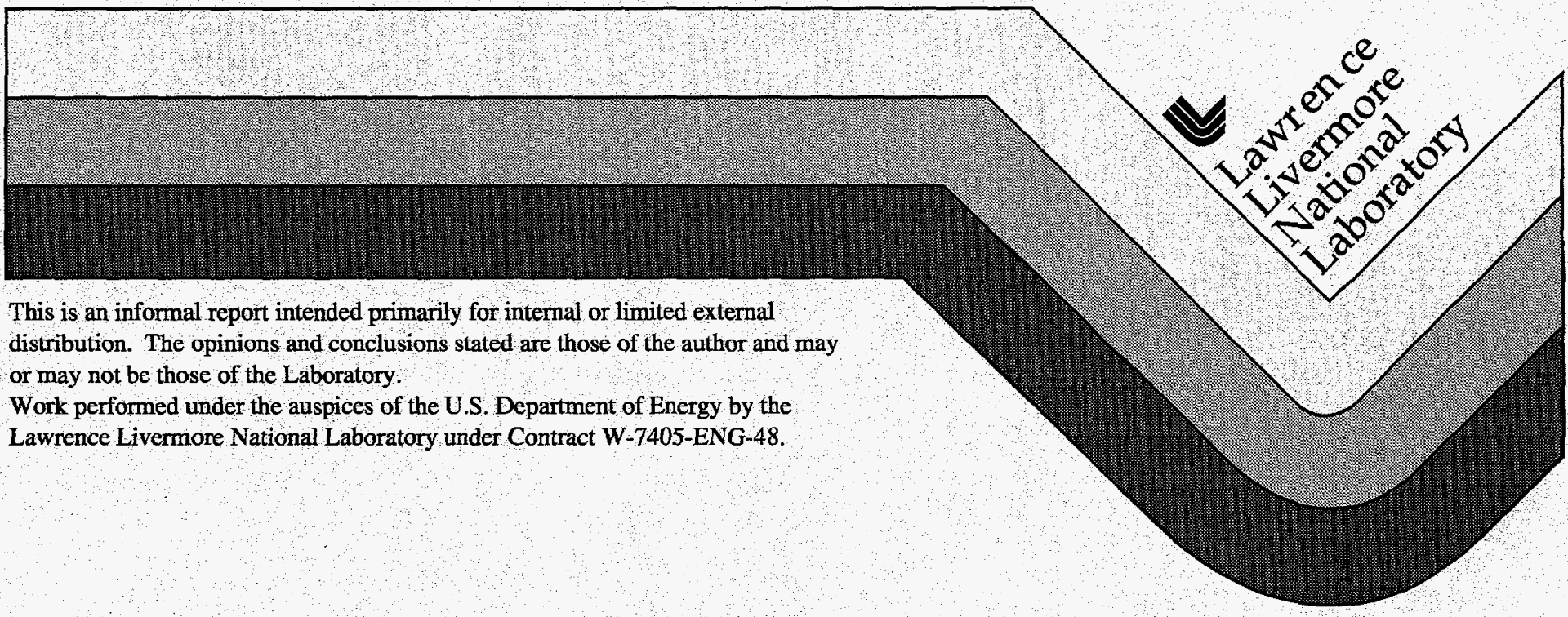




\section{DISCLAIMER}

This document was prepared as an account of work sponsored by an agency of the United States Government. Neither the United States Government nor the University of California nor any of their employees, makes any warranty, express or implied, or assumes any legal liability or responsibility for the accuracy, completeness, or usefulness of any information, apparatus, product, or process disclosed, or represents that its use would not infringe privately owned rights. Reference herein to any specific commercial product, process, or service by trade name, trademark, manufacturer, or otherwise, does not necessarily constitute or imply its endorsement, recommendation, or favoring by the United States Government or the University of California. The views and opinions of authors expressed herein do not necessarily state or reflect those of the United States Government or the University of California, and shall not be used for advertising or product endorsement purposes.

This report has been reproduced

directly from the best available copy.

Available to DOE and DOE contractors from the

Office of Scientific and Technical Information

P.O. Box 62, Oak Ridge, TN 37831

Prices available from (423) 576-8401

Available to the public from the

National Technical Information Service

U.S. Department of Commerce

5285 Port Royal Rd.,

Springfield, VA 22161 


\section{DISCLAIMER}

Portions of this document may be illegible electronic image products. Images are produced from the best available original document. 


\section{Abstract}

A scoping corrosion test was performed on candidate waste package basket materials. The corrosion medium was a pH-buffered solution of chemical species expected to be produced by radiolysis. The test was conducted at $90^{\circ} \mathrm{C}$ for 96 hours. Samples included aluminum-, copper-, stainless steel- and zirconium-based metallic materials and several ceramics, incorporating neutron-absorbing elements. Sample weight losses and solution chemical changes were measured. Both corrosion of the host materials and dissolution of the neutron-absorbing elements were studied. The ceramics and the zirconium-based materials underwent only minor corrosion. The stainless steel-based materials performed well except for a welded sample. The aluminum- and copper-based materials exhibited the highest corrosion rates. Boron dissolution depends on its chemical form. Boron oxide and many metal borides dissolve readily in acidic solutions while high-chromium borides and boron carbide, though thermodynamically unstable, exhibit little dissolution in short times. The results of solution chemical analyses were consistent with this. Gadolinium did not dissolve significantly from monazite, and hafnium showed little dissolution from a variety of host materials, in keeping with its low solubility. 
SCOPING CORROSION TESTS ON CANDIDATE WASTE PACKAGE BASKET MATERIALS FOR THE YUCCA MOUNTAIN PROJECT

Abstract

Introduction

Functions of Waste Package Basket Materials

Projection of Operating Environment for Waste Package Baskets and Selection of Environment for Scoping Corrosion Tests

Selection of Candidate Basket Materials

Description of Scoping Corrosion Tests

Results of Tests

Discussion of Results

Summary and Conclusions

Acknowledgments

References

Appendix A

i

1

1

2

5

7

9

9

16

17

17

A-1 


\section{Introduction}

The U. S. Department of Energy is engaged in the characterization of Yucca Mountain in Nye County, Nevada, to determine its suitability as the site for the nation's first geologic repository for the disposal of commercial nuclear reactor spent fuel and defense high level waste. Lawrence Livermore National Laboratory, as part of the Management and Operating Contractor organization for the Civilian Radioactive Waste Management System, is responsible among other things for recommendation and characterization of potential waste package materials that could be used in a repository at this site, if the site is found to be suitable. ${ }^{1}$

Previously developed conceptual designs for waste packages ${ }^{2,3}$ incorporate a basket assembly into which the spent fuel assemblies are to be inserted. Because these basket assemblies will be required to contribute to nuclear criticality control over an extended period of time, they will need to successfully withstand corrosion and dissolution in the operating environment inside the eventually breached waste packages over this period. Because this is a new materials requirement, and operating experience and test data are not available for the conditions expected, we decided to perform scoping corrosion tests to screen candidate basket materials and develop the understanding necessary to proceed with longer term corrosion testing of promising candidates.

This effort is designated as WBS 1.2.2.5.2 (Basket Materials) under WBS 1.2.2.5 (Waste Package Materials) in the Work Breakdown Structure of the Yucca Mountain Site Characterization Project. It constitutes Activity No. CM-0202 (Scoping Experiments) under Scientific Investigation Plan SIP-CM-02 (Waste Package Basket Materials). ${ }^{4}$ The data presented in this report was collected using applicable Office of Civilian Radioactive Waste Management (OCRWM) Quality Assurance Requirements and Description (QARD) procedures.

\section{Functions of Waste Package Basket Materials}

In the previously developed conceptual designs for waste packages, the basket materials serve three functions:

1. Structural support

2. Heat conduction

3. Nuclear criticality control

These designs incorporate square tubes arranged in a close-packed array, each tube incorporating neutron-absorbing material. Future designs may make use of flux traps (spacing apart of spent fuel assemblies to reduce nuclear reactivity) and may have differing quantitative needs for mechanical integrity, strength, thermal conductivity, and neutron absorption. However, the above three properties will continue to be the important ones. 


\section{Projection of Operating Environment for Waste Package Baskets and Selection of Environment for Scoping Corrosion Tests}

The design environment inside intact waste packages is intended to be dry, inert gas. Achievement of this environment will depend on success in drying, pumping out, backfilling, and sealing these canisters and packages.

If this design environment were achieved as planned and were maintained, corrosion of the basket materials would not be of concern, and neither would criticality. However, given the likelihood of eventual containment failure, most likely by corrosion of the waste package containers, we must consider the likely environments inside packages that have developed leaks. One of the current design assumptions ${ }^{5}$ is that containment could fail for as many as $1 \%$ of the waste packages in the first 1,000 years. The federal regulation establishing the requirement for criticality control (10 CFR Part $60.131(b)(7))^{6}$ does not explicitly specify a time limit, but the current design assumption $^{5}$ is that criticality control will be required for 10,000 years. For comparison, the half-lives of the dominant fissile nuclides in the spent fuel are 24,100 years for ${ }^{239} \mathrm{Pu}$ and 704 million years for ${ }^{235} \mathrm{U} .^{7}$

When containment failure occurs, gaseous and liquid species in the surrounding environment could enter the waste packages. Since inundation by water is considered unlikely for the repository horizon at Yucca Mountain, ${ }^{8}$ the most probable species that would enter are the constituents of moist air. If moist air were the only intruder, repository criticality would not be of concern. However, prudence dictates that we anticipate that significant quantities of liquid water might enter at least some of the packages. In order for this to occur, it would have to take place by liquid transport via fracture flow. Condensation onto the packages is not considered because the packages will always be at higher temperatures than their environment due to nuclear decay heat. Liquid transport from the geologic environment would mean that the solutes present in vadose water would also enter the packages. An example of the ground water present in the rock of the repository horizon (Topopah Spring tuff) is that obtained from Well $\mathrm{J}-13$. Its analysis is shown in Table $1 .{ }^{9}$

One of the current design assumptions ${ }^{5}$ is that the centerline temperature in the waste packages containing spent nuclear fuel will not exceed $350^{\circ} \mathrm{C}$. Because the pressure in the repository will be about one atmosphere, liquid water cannot be present in a failed waste package until its temperature has dropped below about $100^{\circ} \mathrm{C}$, depending on the presence of hygroscopic salts, some of which can raise this temperature limit somewhat.

It is not possible to accurately predict when a given waste package will fail, what the temperature will be at that time, and when liquid water might be available to enter a failed package. It is also not possible to accurately predict what the radiation dose rates will be at the time these events occur. 
Table 1

\section{Composition of Well J-13 Water ${ }^{9}$}

\begin{tabular}{|c|c|}
\hline Element or lon & Concentration $(\mathrm{mg} / \mathrm{L})$ \\
\hline \hline $\mathrm{Na}$ & 46 \\
\hline $\mathrm{Si}$ & 29 \\
\hline $\mathrm{Ca}$ & 13 \\
\hline $\mathrm{K}$ & 5 \\
\hline $\mathrm{Mg}$ & 2 \\
\hline $\mathrm{B}$ & 0.13 \\
\hline $\mathrm{Al}$ & 0.04 \\
\hline $\mathrm{HCO}_{3}^{-}$ & 129 \\
\hline $\mathrm{SO}_{4}^{2-}$ & 18 \\
\hline $\mathrm{NO}_{3}^{-}$ & 9 \\
\hline $\mathrm{Cl}^{-}$ & 7 \\
\hline $\mathrm{F}$ & 2 \\
\hline & \\
\hline
\end{tabular}

In the presence of these uncertainties, we can envision a variety of scenarios. Consideration of worst cases is appropriate because it is required by $10 \mathrm{CFR} 60^{6}$ to avoid criticalities in all the waste packages, whatever their individual circumstances. The worst cases are thus of most interest. Perhaps the worst case would be early containment failure, while there is still significant heat output from strontium-90 and cesium-137. In this case only humid atmospheric gases could enter the package initially, because the temperature would be above the boiling point of water.

In this worst case scenario, the temperature might be sufficiently high and the oxygen sufficiently plentiful for the spent fuel cladding to fail ${ }^{10}$. Cladding failure would, in turn, cause oxidation of the $\mathrm{UO}_{2}$ fuel to $\mathrm{U}_{3} \mathrm{O}_{8}$ which would result in splitting of the cladding and crumbling of the pellets into powder. In this case, the gases and, later, liquids entering the waste package would be exposed to alpha and beta radiation in addition to the gamma radiation that would be emitted by intact fuel, and the dose rate could be in the range of hundreds of grays per hour. ${ }^{11,12}$ Upon cooling below the boiling point, in the worst case, liquid vadose water could then enter the package, bringing in its solutes. This case would involve significant radiolysis. Whether this sequence of events can be considered to consist of "at least two unlikely, independent, and concurrent or sequential changes in the conditions essential to nuclear criticality safety," in the words of the regulation ${ }^{6}$, is subject to interpretation.

As can be seen in Table 1 , Well $\mathrm{J}-13$ water contains $129 \mathrm{mg} / \mathrm{L}$ of bicarbonate, and has near-neutral $\mathrm{pH}$. If water having this composition entered a failed waste package at near current ambient temperatures, the bicarbonate would initially buffer the $\mathrm{pH}$ near neutral. However, if sufficient acid were produced by radiolysis, the buffer would be overcome, and the $\mathrm{pH}$ would drop. 
In less extreme scenarios, containment would be maintained until sufficient cooling occurred that the $\mathrm{UO}_{2}$ would not oxidize and crumble. The air and water that entered would then be subject only to gamma irradiation, and the dose rates would be much lower because of decay of 30 -year half-life ${ }^{137} \mathrm{Cs}$, the dominant gamma emitter. In such a case, radiolysis might not be a significant factor.

Because of the uncertainty involved in predicting the course of events, we have chosen to perform scoping tests using a corrosion environment that contains significant concentrations of the chemical species known to be produced by irradiation of an air-water system, that are also known to be important in corrosion. Reviews of radiation chemistry in moist air and moist airwater systems have been presented. ${ }^{13,14}$

Barkatt et al. ${ }^{15}$ reported the results of experiments in which an airdeionized water system was gamma-irradiated at room temperature. The observed radiolytic species were nitric, formic, and oxalic acids and hydrogen peroxide. For a total dose of $6.2 \times 10^{4}$ Gy over a 3-day period at $25^{\circ} \mathrm{C}$, the concentrations of these species, respectively, were $78,46,30$, and 16 umoles/liter. This dose is orders of magnitude smaller than what could be reached in an early-failing waste package over a period of hundreds of years.

In the above work, nitric acid formed by radiolysis in the gas phase which then condensed into the liquid phase. Hydrogen peroxide formed in the liquid phase. The formic and oxalic acids formed from dissolved $\mathrm{CO}_{2}$ in the liquid phase but only after the $\mathrm{pH}$ had been lowered to about 4 by nitric acid production. $^{14}$

In order to be able to perform scoping tests conveniently, at relatively low cost, and in a short time, we chose to simulate the effects of irradiation by ordinary chemical means. In so doing, we recognize that transient, free radical effects have been ignored. We have also elected to use concentrations of radiolytic species much higher than those observed by Barkatt et al. in order to make possible a batch-type experiment that would show observable results in a short time, and to account for the fact that the repository time-scale of interest is several orders of magnitude longer and the resulting worst-case doses are orders of magnitude higher than those in the Barkatt et al. experiments. In addition to radiolytic species, we have included chloride since it is present in Well $\mathrm{J}-13$ water and is known to be important in corrosion of many metals.

In order to provide a controlled-pH environment, we have also chosen to formulate the corrosion medium as a buffered-pH solution. Any changes in the $\mathrm{pH}$ of this buffered solution during testing would, thus, be an indication of significant chemical reaction with the test specimen. It is well known that a weak acid provides optimum buffering when its $\mathrm{pK}$ value (negative logarithm of the dissociation constant) is equal to the $\mathrm{pH}$ of the solution. ${ }^{16,17}$ Thus, for test solutions with a $\mathrm{pH}$ near 4 , the presence of formic and oxalic acids with $\mathrm{pK}$ 
values of 3.75 and 4.27 , respectively, at $25^{\circ} \mathrm{C}^{17}$ should provide for good buffering.

We chose the temperature to be comfortably below the boiling point to facilitate control, but high enough to produce significant reaction rates. The repository temperatures will span a range from well above boiling down to ambient over the course of time.

\section{Selection of Candidate Basket Materials}

Ideally one would like to have a single material that could perform all the functions listed above at reasonable cost and with good long-term corrosion performance. However, as is often the case, these various requirements are not satisfied by a single substance, and compromises must be made. For structural support, metals are preferred, and in particular, those with significant strength at the peak temperature of $350^{\circ} \mathrm{C}$. High thermal conductivity would suggest aluminum or copper of the commonly used metals. Chemical elements with high neutron absorption cross sections include lithium, boron, silver, cadmium, gadolinium (and other lanthanides), and hafnium. Materials best able to withstand the projected corrosion environment would include stainless steels, high-nickel alloys, zirconium alloys, and some ceramics. Of the metals mentioned here, aluminum and copper are the least costly. Of the elements with high neutron absorption cross sections, the least soluble in water over a wide $\mathrm{pH}$ range is hafnium.

In the presence of these conflicting properties and requirements, we have chosen to test a variety of candidates, taking into account the functions of the basket, past experience with materials in similar applications (reactor control rods and neutron absorbers for pool storage of spent fuel, shipping casks, and neutron shielding), ${ }^{18-20}$ the requirement for "reasonable" cost, ${ }^{21}$ and the need for good corrosion performance. Candidates under consideration by waste package designers were included, as were some developmental materials and some ceramics based on naturally occurring minerals, expected to have high durability under repository waste package conditions.

The candidates that were tested are listed in Table 2. More detailed descriptions of the actual samples used are given in Appendix A. The aluminum- and copper-based materials provide the high thermal conductivity of the base metal and incorporate a form of boron for neutron absorption. Since boron exhibits very low solid solubility in both aluminum and copper, it is present as a dispersed phase. In the case of aluminum and its alloys, addition of boron produces borides, $\mathrm{AlB}_{2}$ and others. In the case of alloying with copper, boron exists as the element. In both aluminum and copper, boron can also be incorporated as boron carbide. Samples representing all of these approaches have been included. Boral ${ }^{\mathrm{TM}}$ and Boralyn ${ }^{\mathrm{TM}}$ are commercial products; the other aluminum-based materials are developmental. The "A॰B"TM material was originally developed for light armor applications. Boral ${ }^{\mathrm{TM}}$ which had been anodized by AAR Advanced Structures for improved corrosion resistance was tested separately after the others at the request of one of the reviewers of a draft 
version of this report. Since the anodized layer could potentially become scratched, both unscratched and intentionally scratched anodized Boral $\mathrm{TM}^{\mathrm{M}}$ samples were tested to determine whether scratches have a significant effect on corrosion performance.

Table 2

Candidate Basket Materials Tested

\begin{tabular}{|c|c|}
\hline \multirow{3}{*}{ Alboron $^{\mathrm{TM}}$} & Aluminum (Alloy 1100) with dispersed aluminum boride \\
\hline & Aluminum(Alloy 6061) with dispersed aluminum boride \\
\hline & Aluminum(Alloy 6351) with dispersed aluminum boride \\
\hline Boralyn $^{T M}$ & Aluminum with finely dispersed boron carbide \\
\hline \multirow{2}{*}{$\begin{array}{c}\text { Boral }^{\mathrm{TM}} \\
\text { Anodized Boral }^{\mathrm{TM}}\end{array}$} & Aluminum-boron carbide composite \\
\hline & Anodized aluminum-boron carbide composite \\
\hline$\overline{A \cdot B^{\mathrm{TM}}}$ & Aluminum oxide-boron carbide ceramic \\
\hline \multirow[t]{2}{*}{ Cu/boron } & Copper with dispersed elemental boron \\
\hline & Copper with dispersed boron carbide \\
\hline \multirow[t]{2}{*}{$\begin{array}{l}\text { Glidcop } A-15^{\mathrm{TM}} \\
\text { with boron }\end{array}$} & $\begin{array}{l}\text { Copper with dispersed aluminum oxide and elemental } \\
\text { boron }\end{array}$ \\
\hline & Copper with dispersed aluminum oxide and boron carbide \\
\hline Type 304L Steel & Austenitic stainless steel without boron used as a control \\
\hline $\begin{array}{l}\text { Bohler Brothers } \\
\text { A976 }\end{array}$ & $\begin{array}{l}\text { Austenitic stainless steel with dispersed borides made by } \\
\text { melting }\end{array}$ \\
\hline \multirow{2}{*}{$\begin{array}{c}\text { Carpenter } \\
\text { Technology } \\
\text { Neutrosorb } \\
\text { PLUS }\end{array}$} & $\begin{array}{l}\text { Austenitic stainless steel with dispersed borides made by } \\
\text { powder metallurgy-base metal }\end{array}$ \\
\hline & $\begin{array}{l}\text { Austenitic stainless steel with dispersed borides made by } \\
\text { powder metallurgy-welded }\end{array}$ \\
\hline $\begin{array}{c}\text { Teledyne Wah } \\
\text { Chang } \\
\text { Zircadyne } 702^{\mathrm{TM}}\end{array}$ & Zirconium-hafnium \\
\hline Boron carbide & Hot pressed \\
\hline $\begin{array}{c}\text { Hafnium } \\
\text { oxide/Yyttrium } \\
\text { oxide }\end{array}$ & Hot pressed hafnium oxide with 5 wt.\% yttrium oxide \\
\hline Monazite & Hot pressed gadolinium phosphate \\
\hline Zircon & Hot pressed zirconium silicate containing hafnium \\
\hline Zirconolite & hot pressed calcium zirconium titanate containing hafnium \\
\hline
\end{tabular}

The boron-alloyed stainless steels are commercial products. The Bohler material is melted and rolled. The boron in this steel precipitates as mixed metal borides which become elongated during processing. The Neutrosorb PLUS ${ }^{\mathrm{TM}}$ is made by a powder metallurgy process, and its mixed metal borides are more nearly spherical in shape, more uniform in size, and more homogeneously distributed. In both cases, the borides are chromium- and iron-rich with a small amount of nickel, as determined by scanning electron microscopy-energy dispersive $\mathbf{x}$-ray spectroscopy (SEM-EDS). 
The Zircadyne $702^{\mathrm{TM}}$ is a commercial product composed of essentially pure zirconium, but including the hafnium that occurs naturally in the ore with zirconium. Hafnium is a good neutron absorber and is separated from the zirconium when the latter is used to make zircaloy cladding for reactor fuel. However, leaving the hafnium in would be beneficial for a basket material, and the cost of the zirconium is actually lower if the separation is not performed and the hafnium remains.

Boron carbide and hafnium oxide samples were tested to determine the dissolution of these neutron absorbers as bulk ceramic materials. Yttria was added to hafnium oxide to stabilize the high-temperature tetragonal crystal structure.

Gadolinium is a strong neutron absorber, and it was incorporated as monazite (gadolinium phosphate) because of the known chemical durability of natural monazite. Zircon and zirconolite were tested as hosts for hafnium because of their known durability in the natural state as well.

\section{Description of Scoping Corrosion Tests}

The corrosion test cells used were Pyrex ${ }^{\mathrm{TM}}$ 1000-ml three-neck flasks (see Fig. 1). One port was fitted with a Pyrex condenser to capture evaporated water and return it to the vessel. A second port was fitted with a thermometer. The third was used for filling and was capped with a Pyrex plug. Teflon ${ }^{\mathrm{M}}$ seals were used with no grease. This glassware was cleaned before the tests by rinsing with $10 \%$ sodium hydroxide solution, followed by rinsing with $1 \mathrm{M}$ nitric acid; followed by rinsing with distilled water.

The composition of the corrosion medium was intended to be as follows:

$0.01 \mathrm{M}$ formic acid (methanoic acid, $\mathrm{HCOOH}$ )

$0.01 \mathrm{M}$ sodium formate $(\mathrm{NaCOOH})$

$0.02 \mathrm{M}$ sodium oxalate $\left(\mathrm{Na}_{2} \mathrm{C}_{2} \mathrm{O}_{4}\right)$

$0.01 \mathrm{M}$ nitric acid $\left(\mathrm{HNO}_{3}\right)$

$0.01 \mathrm{M}$ sodium chloride $(\mathrm{NaCl})$

$0.01 \mathrm{M}$ hydrogen peroxide $\left(\mathrm{H}_{2} \mathrm{O}_{2}\right)$

in distilled water

With this formulation, hydrogen ions from the strongly ionizing nitric acid associate with about half of the oxalate to form oxalic acid. The formic and oxalic acids, together with their salts, buffer the $\mathrm{pH}$. This solution was used, as intended, for all but samples \#1 through 5 . For samples \#1 through 5 , the formic acid was inadvertently left out of the solution. Although formate was still present, the $\mathrm{pH}$ buffering was not as robust for these samples, as evidenced in Table 3 of the next section by comparison of the final pH of solution \#5 (the first control) with that of solutions \#28 and 32 (subsequent controls).

Approximately $700 \mathrm{ml}$ of solution was used in each test vessel. Vessels were weighed before and after filling and at the end of tests to determine water 
loss. Each vessel was heated using a heating mantle, in which its bottom was nested. Temperature control was accomplished by manual adjustment of Variac $^{T \mathrm{M}}$ transformers. The temperatures were maintained at $90 \pm 5^{\circ} \mathrm{C}$ for the test duration of 96 hours, except for sample \#19, which was terminated at 90 hours, after extensive corrosion, because the data were needed for a requested presentation at the Management and Operating Contractor (M. \& O.) headquarters. The thermometers were calibrated in an ice bath and in boiling distilled water. The solutions were kept mixed by free convection, driven by the heating mantles. The $\mathrm{pH}$ of each solution was measured at room temperature before and after the test, using a calibrated $\mathrm{pH}$ meter. For solutions \#1 through 5 , the initial $\mathrm{pH}$ was 4.06 . For the others, it was $\mathrm{pH} 3.80$ to $\mathrm{pH} 3.82$.

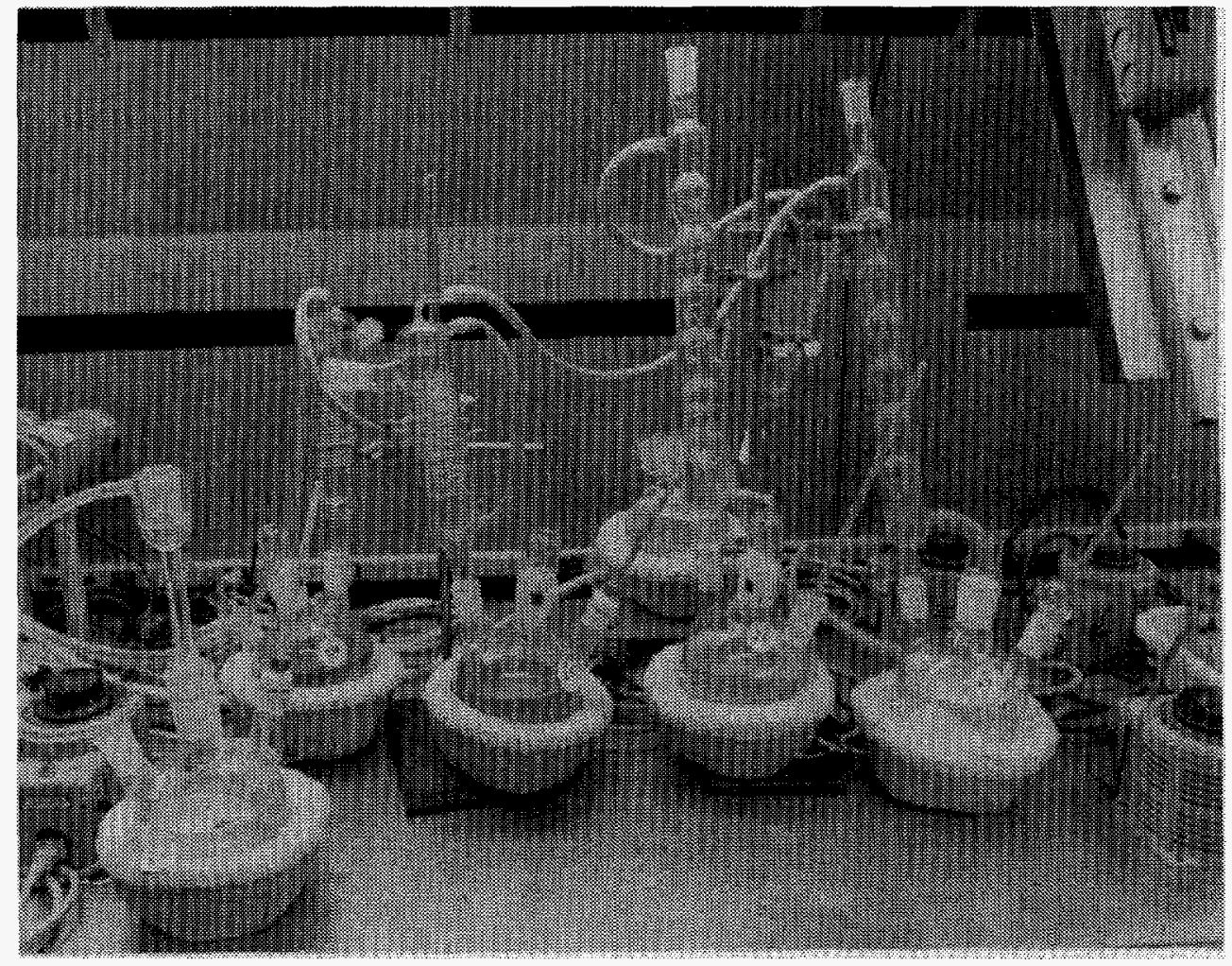

Figure 1. Corrosion Test Setup

Unfiltered samples of each solution were chemically analyzed before and after the tests, using ion chromatography and inductively-coupled plasma optical emission spectrometry (ICP-OES). lodometric titration was performed to determine peroxide but suffered from interferences in some of the solutions. For that reason, the peroxide results are omitted. Observed precipitates were analyzed by X-ray diffraction. Metallography and SEM-EDS were performed on some of the samples initially. Each sample was sanded smooth using 600grit paper and was then ultrasonically cleaned using acetone, methanol, and distilled water in succession. Samples were weighed before and after testing using a calibrated electronic balance with a precision of $\pm 1 \mathrm{mg}$. With the exception of the unwelded stainless steel specimens and alloy 702 , which had 
very thin, uniform corrosion products, the metal specimens were cleaned according to ASTM Standard Practice G1-90 ${ }^{22}$ prior to the final weight measurement. Samples were examined by metallograph after cleaning. The edges of the anodized Boral ${ }^{\mathrm{TM}}$ samples were coated with 1201 red enamel produced by Glyptal, Inc., in order to focus on the effect of anodizing the aluminum surface. This enamel was difficult to remove in some cases, however, leading to uncertainty in some of the final weight measurements.

\section{Results of Tests}

The following observations were made while the tests were in progress:

1. For all four copper-based samples, the solutions turned bright blue during initial warmup.

2. For the welded Neutrosorb PLUS sample (\#19), the solution initially became yellow-green in color, then abruptly changed to turbid brown. Then a brown precipitate dropped out over a period of hours, and the solution became clear again.

3. The solutions remained clear for all the other samples.

4. The aluminum- and the copper-based samples evolved gas bubbles.

The corrosion and $\mathrm{pH}$ results are given in Table 3, and the final solution compositions are shown in Table 4. Solution weight losses were found to be less than 4\%. Photomicrographs of samples \#3 and \#19 are shown in Figures 2 and 4. Figure 3 is representative of the anodized Boral ${ }^{\mathrm{TM}}$ samples. X-ray diffraction analysis of the precipitate from sample \#19 indicated hematite $\left(\mathrm{Fe}_{2} \mathrm{O}_{3}\right)$ as a major constituent and halite $(\mathrm{NaCl})$ and sodium oxalate $\left(\mathrm{Na}_{2} \mathrm{C}_{2} \mathrm{O}_{4}\right)$ as minor constituents.

\section{Discussion of Results}

Considering the first control solution (\#5) in Table 4, it can be seen that the initial concentrations of formate, oxalate, nitrate, and chloride were essentially preserved, and boron pickup from the Pyrex vessel amounted to only $0.22 \mu \mathrm{g} / \mathrm{ml}$ or $2.0 \times 10^{-5} \mathrm{M}$. The pH increased from 4.06 initially to 4.73 (see Table 3) at the end. As noted earlier, the formic acid was inadvertently left out of solutions \#1 through 5, which includes the first control. Had it been put in as intended, the initial pH would have been 3.80 to 3.82 , and the final pH would have been approximately 3.88 as observed for control solutions \#28 and 32 . Considering the three control solutions together, the analyses demonstrate that the solution is sufficiently thermally stable for the time period used, that the $\mathrm{pH}$ buffer is effective for the time and temperature used, and that boron dissolution from the Pyrex vessels is minimal. For the sample in the first batch that did not undergo significant corrosion (\#1), the omission of formic acid is not significant because the $\mathrm{pH}$ buffer was not seriously challenged, and formic acid is not a 
chelating agent. For those that did corrode significantly (\#2-4), one might expect even more corrosion if the buffer had been more robust.

Table 3

Corrosion and $\mathrm{pH}$ Results

\begin{tabular}{|c|c|c|c|c|}
\hline $\begin{array}{c}\text { Sample } \\
\text { No. }\end{array}$ & Sample & $\begin{array}{c}\text { Mass } \\
\text { Loss (g) }\end{array}$ & $\begin{array}{c}\text { Corrosion } \\
\text { Rate } \\
(\mathrm{mm} / \mathrm{y})^{\mathrm{A}}\end{array}$ & $\begin{array}{c}\text { Final } \\
\mathrm{pH}\end{array}$ \\
\hline$\overline{\overline{5}}$ & Control & - & $\overline{-1}$ & 4.73 \\
\hline 2 & $1100 \mathrm{Al}-4.3$ wt. $\%{ }^{10} \mathrm{~B}$ & 0.070 & $1.9^{B}$ & 7.13 \\
\hline 8 & $6061 \mathrm{Al}-0.6$ wt. $\%{ }^{10} \mathrm{~B}$ & 0.124 & $2.4^{B}$ & 6.85 \\
\hline 9 & $6351 \mathrm{Al}-0.5$ wt. $\%{ }^{10} \mathrm{~B}$ & 0.088 & $2.6^{B}$ & 7.03 \\
\hline 7 & Boralyn & 0.133 & $1.6^{B}$ & 6.80 \\
\hline 3 & Boral & 0.061 & $1.8^{B}$ & 7.32 \\
\hline 29 & \multirow{3}{*}{ Anodized Boral } & 0.010 & 0.26 & 6.52 \\
\hline $30^{c}$ & & 0.118 & 3.0 & 6.57 \\
\hline 31 & & 0.084 & 2.2 & 6.65 \\
\hline 32 & Control & - & - & 3.89 \\
\hline $33^{\mathrm{C}}$ & \multirow{3}{*}{ Anodized Boral } & 0.545 & 16.6 & 6.35 \\
\hline 34 & & 0.133 & $3.5^{\circ}$ & 6.52 \\
\hline $36^{c}$ & & 0.229 & 6.2 & 6.52 \\
\hline 23 & $\overline{A \cdot B}$ & 0.025 & $0.60^{\mathrm{B}}$ & 4.08 \\
\hline 24 & Cu-1.5 wt.\% B & 0.263 & 2.3 & 4.14 \\
\hline 25 & GlidCop-1.5\% wt.\% B & 0.240 & 1.9 & 4.14 \\
\hline 4 & Cu-1.8 wt. \% B4C & 0.146 & 1.8 & 5.11 \\
\hline 10 & GlidCop-1.8 wt.\%B4C & 0.088 & 1.3 & 4.07 \\
\hline 20 & $304 \mathrm{~L}$ SS & 0.003 & 0.01 & 3.99 \\
\hline 26 & Bohler A976 SD & $\overline{0.011}$ & 0.04 & 4.16 \\
\hline 22 & Neutrosorb PLUS-base & 0.007 & 0.06 & 4.49 \\
\hline 19 & Neutrosorb PLUS-welded & 0.125 & $0.77^{B}$ & 6.37 \\
\hline 1 & Zircadyne 702 & 0.003 & 0.05 & 4.26 \\
\hline 14 & $\mathrm{~B} 4 \mathrm{C}$ & 0.001 & 0.05 & 3.88 \\
\hline 18 & $\mathrm{HfO}_{2}-5$ wt.\% $\mathrm{Y}_{2} \mathrm{O}_{3}$ & 0.002 & 0.03 & 3.88 \\
\hline 16 & Gd-monazite & 0.003 & 0.19 & 3.88 \\
\hline 17 & Zircon-5 wt. $\% \mathrm{HfO}_{2}$ & 0.002 & 0.07 & 3.88 \\
\hline 13 & Zirconolite-5 wt.\%Hf02 & 0.029 & 1.1 & 3.88 \\
\hline 28 & Control & - & - & 3.88 \\
\hline
\end{tabular}




\section{Table 4 \\ Final Solution Compositions $\left(10^{-4} \mathrm{M}\right)$}

\begin{tabular}{|c|c|c|c|c|c|c|c|c|c|c|}
\hline $\begin{array}{c}\text { Sample } \\
\text { Number }\end{array}$ & Formate & Oxalate & $\mathrm{NO}_{3}^{-}$ & $\mathrm{Cl}^{-}$ & $\mathrm{B}$ & $\mathrm{Al}$ & $\mathrm{Cr}$ & $\mathrm{Fe}$ & $\mathrm{Ni}$ & Other \\
\hline \hline 5 & 91 & 170 & 93 & 93 & 0.20 & $<0.03$ & & & & \\
\hline 2 & 93 & 200 & 90 & 94 & 4.39 & 31 & & & & \\
\hline 8 & 170 & 200 & 80 & 90 & 0.98 & 52 & & & & \\
\hline $9 \cdot$ & 150 & 180 & 90 & 90 & 0.40 & 38 & & & & \\
\hline 7 & 170 & 200 & 70 & 90 & 0.23 & 52 & & & & \\
\hline 3 & 97 & 190 & 89 & 92 & 0.90 & 31 & & & & \\
\hline 29 & 124 & 101 & 95 & 110 & 0.70 & 56 & & & & \\
\hline 30 & 109 & 99 & 89 & 109 & 0.48 & 55 & & & & \\
\hline 31 & 143 & 99 & 88 & 108 & 0.68 & 54 & & & & \\
\hline 32 & 196 & 102 & 101 & 107 & 0.26 & $<0.04$ & & & & \\
\hline 33 & 147 & 99 & 77 & 110 & 0.80 & 59 & & & & \\
\hline 34 & 140 & 99 & 95 & 108 & 0.70 & 59 & & & & \\
\hline 36 & 169 & 104 & 99 & 113 & 0.31 & 58 & & & & $48.5 \mathrm{Cu}$ \\
\hline 23 & 181 & 199 & 98 & 96 & 4.13 & 1.35 & & & & $29.7 \mathrm{Cu}$ \\
\hline 24 & 199 & 234 & 97 & 97 & 0.42 & & & & & $18.7 \mathrm{Cu}$ \\
\hline 25 & 195 & 232 & 94 & 95 & 0.30 & 0.13 & & & & \\
\hline 4 & 85 & 180 & 97 & 95 & 0.31 & & & & & \\
\hline 10 & 160 & 200 & 100 & 100 & 0.27 & $<0.03$ & & & & \\
\hline 20 & 170 & 200 & 99 & 100 & 0.06 & & 0.025 & 0.21 & $<0.03$ & \\
\hline 26 & 150 & 190 & 93 & 95 & 0.13 & & 0.35 & 1.56 & 0.27 & \\
\hline 22 & 120 & 190 & 110 & 110 & 0.12 & & 0.02 & 0.94 & 0.19 & \\
\hline 19 & 72 & 150 & 96 & 94 & 0.17 & & 2.38 & 7.25 & 2.37 & \\
\hline 1 & 93 & 200 & 90 & 92 & 0.32 & & & & & $0.002 \mathrm{Hf}$ \\
\hline 14 & 170 & 210 & 100 & 90 & 0.10 & & & & & \\
\hline 18 & 180 & 200 & 100 & 100 & 0.13 & & & & & $0.002 \mathrm{Y}, 0.005 \mathrm{Hf}$ \\
\hline 16 & 160 & 200 & 100 & 90 & 0.19 & & & & & $0.23 \mathrm{P}, 0.02 \mathrm{Gd}$ \\
\hline 17 & 160 & 200 & 90 & 90 & 0.20 & & & & & $0.37 \mathrm{Si}, 0.02 \mathrm{Zr}, 0.003 \mathrm{Hf}$ \\
\hline 13 & 170 & 270 & 100 & 100 & 0.22 & & & & & $0.11 \mathrm{Ca}, 0.14 \mathrm{Ti}, 0.02 \mathrm{Zr}$, \\
\hline 28 & 190 & 190 & 82 & 94 & & & & & & \\
\hline
\end{tabular}

Turning to the aluminum metal-based samples (\#2, 8, 9, 7 and 3 ), considerable oxidation of aluminum occurred. An example is given in Figure 2 below. The samples were pitted, exhibiting "equivalent" uniform corrosion rates of about $2 \mathrm{~mm} / \mathrm{y}$. Aluminum was dissolved in the solution, hydrogen gas (presumably) was evolved, and the $\mathrm{pH}$ buffer was overwhelmed. The boron concentration in the solution was observed to increase, except in the case of Boralyn. The aluminum observations are consistent with the known behavior of aluminum in acidic solutions, as discussed in a previous unpublished paper. ${ }^{23}$ For samples \#2, 8, and 9, it is understandable why the boron concentration in solution rose. The boron is primarily in the form of borides in these samples, ${ }^{24,25}$ and most borides are soluble in acidic solutions. ${ }^{26}$ As can be seen from sample \#14, however, bulk boron carbide did not dissolve significantly in 96 hours under these experimental conditions. The increase in dissolved boron in the case of Boral (\#3), which contains boron primarily as the carbide, must therefore be due to soluble $\mathrm{B}_{2} \mathrm{O}_{3}$, which is included at small concentrations by the manufacturer ${ }^{27}$ in order to assist in passivating the aluminum when the material is used in spent 
fuel pools. In Boralyn (\#7), the $\mathrm{B}_{4} \mathrm{C}$ particles are reported by the manufacturer to be coated with a proprietary material. ${ }^{28}$

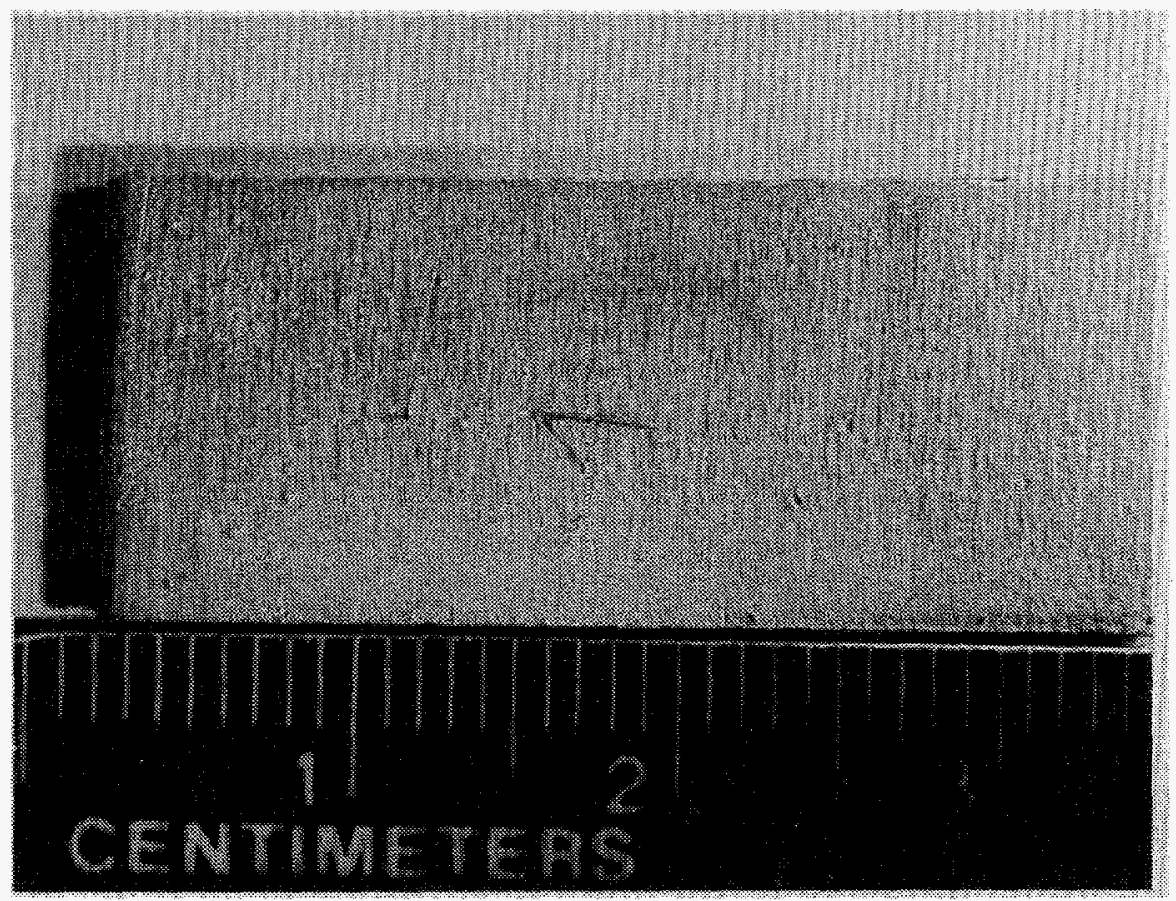

Figure 2. Boral Sample (\#3) after Corrosion and Cleaning

The anodized Boral (\#29-31, 33, 34 and 36) did not perform better than as-processed Boral. Pitting was not observed in the anodized specimens, but in most cases, higher corrosion rates were seen. There is some scatter in the corrosion rates recorded in Table 3. This scatter is believed to be due to the enamel applied to the edges of the anodized Boral specimens. In some cases, it was difficult to remove, leading to errors in the final weight of the corroded specimens. It does appear, however, that scratching the surface did increase the corrosion rate. Variation in the integrity of this enamel coating is also most likely responsible for the scatter in the boron dissolved into the solution (Table 4). The amount of aluminum in solution, however, is fairly independent of anodizing conditions or whether the sample was scratched or not. It is also consistent with that seen with the other aluminum samples and is higher than that seen with Boral sample \#3.

Figure 3 is an SEM micrograph of the surface of specimen \#30. This specimen was fractured by bending after corrosion so that the damaged surface profile could be seen. The ribbed region on the left half of the surface is the original anodized layer. This area was near the edge of the specimen and was inadvertently coated with the Glyptal enamel. As a result, it was not exposed to the corrosion medium and does not show any signs of chemical attack. The "ribbed" structure is due to cracking during the post-corrosion bending. The right side of the surface did not have the Glyptal coating and was heavily attacked. The corrosion seen in this micrograph extends through the oxide layer and penetrates into the underlying aluminum cladding. 


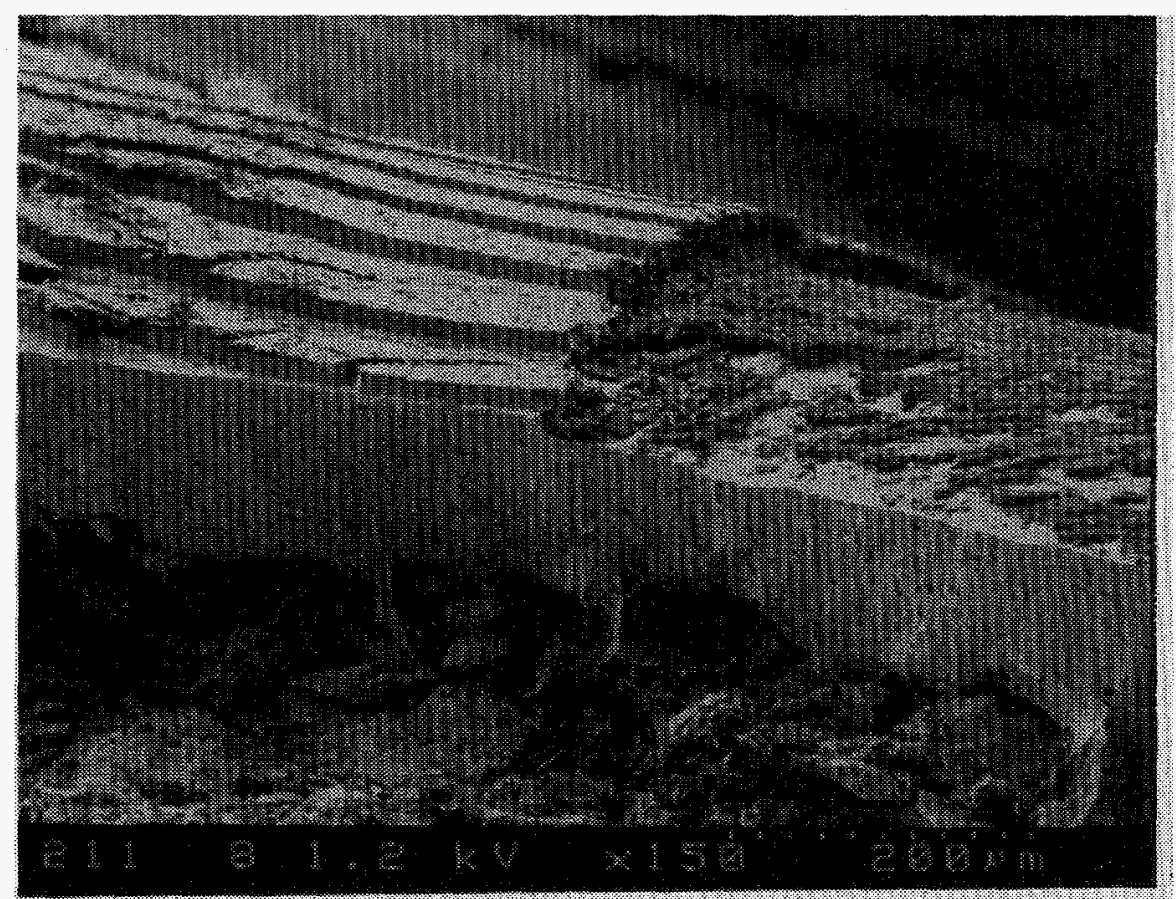

Figure 3. Anodized Boral Sample (\#30) after Corrosion and Cleaning

The A.B sample (\#23) performed somewhat better than the aluminum metal-based materials in terms of weight loss, but the boron loss to the solution was high. This is probably due to the formation of soluble boron oxides during hot pressing.

The copper-based samples (\#24, 25, 4, and 10) exhibited corrosion rates comparable to those of the aluminum-based samples but did not overcome the $\mathrm{pH}$ buffer. This apparent discrepancy is presumably due to the fact that copper becomes soluble after only one electron is removed while aluminum has an oxidation state of +3 in solution. Less acid must therefore be used up in dissolving copper than aluminum on an equimolar basis. The $\mathrm{B}_{4} \mathrm{C}$-containing copper-based samples (\#4 and 10) did not release significant amounts of boron to the solution, again consistent with the bulk $\mathrm{B}_{4} \mathrm{C}$ behavior. GlidCop A-15 (\#25 and 10) showed somewhat better corrosion resistance than did the pure copper (\#24 and 4). The observations with the copper-based samples are consistent with the known behavior of copper in oxidizing acid solutions. ${ }^{29}$

The stainless steel-based samples (\#20, 26, 22, and 19) performed well except for the weld on sample \#19, which exhibited knife-line attack along its edge as well as attack on the body of the weld (Fig. 4). The structure of the weld zone on sample \#19 was found by SEM-EDS to consist of dendritic austenite surrounded by a eutectic structure composed of austenite and boride phases, as described by Robino and Cieslak. ${ }^{30}$ The corrosion attack appeared to have occurred preferentially on the austenite phase. This is consistent with the low 
boron concentration observed in the solution and the known resistance of chromium boride to attack by acids. ${ }^{26}$

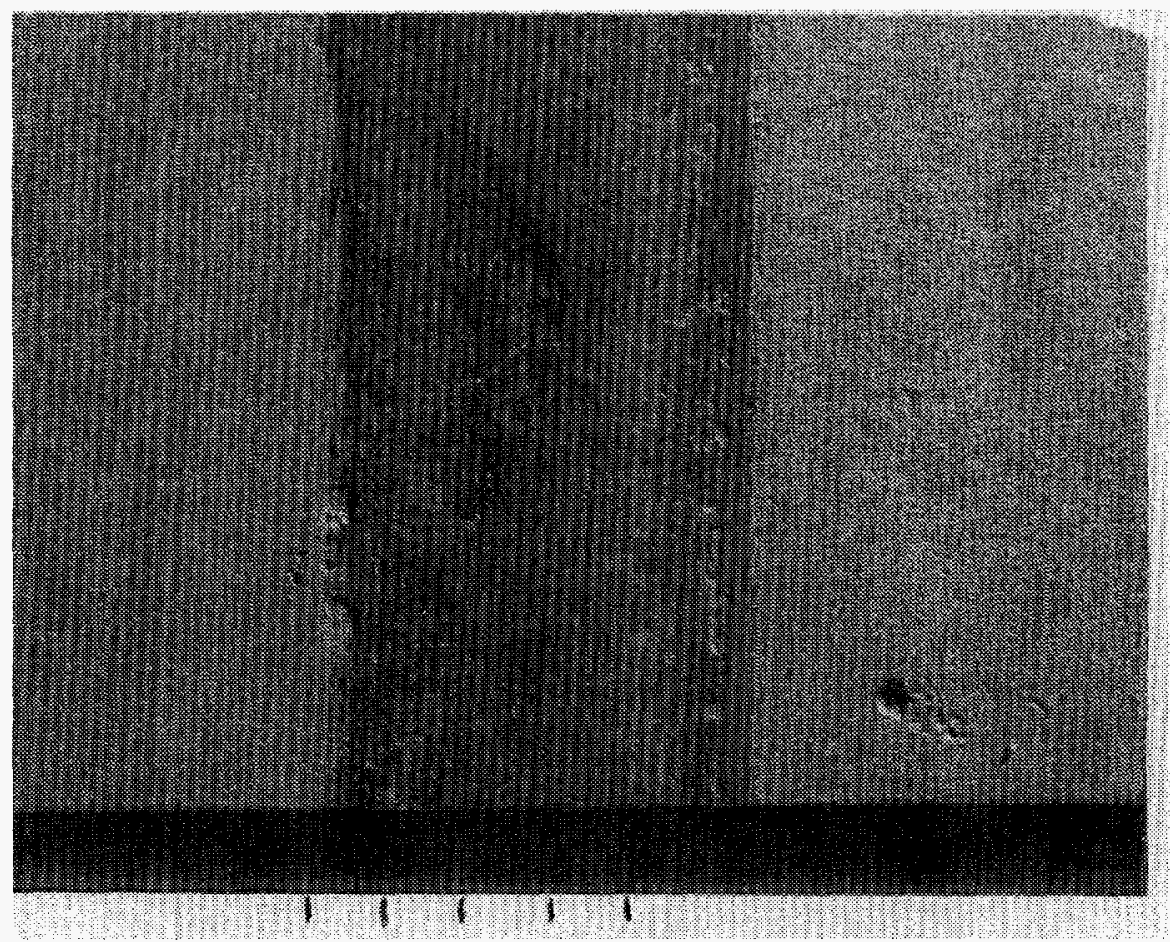

Figure 4. Weld on Neutrosorb PLUS Sample (\#19) after Corrosion (1-mm divisions on scale at bottom)

The chemistry of the solution for sample \#19 is complex. Probably the initial yellow-green color of the solution was due to ferrous iron. It can be expected that this would have formed initially during corrosion of the austenite phase. Oxalic acid is known to stabilize iron in the ferrous state, and oxidation by hydrogen peroxide is generally slow in acidic solutions. ${ }^{31}$ However, ferrous iron eventually will react with hydrogen peroxide to produce (brown) ferric iron, hydroxide ion, and hydroxyl free radical via the Fenton reaction. The hydroxyl free radical in turn will rapidly decompose formic and oxalic acids. Furthermore, ferric iron is a catalyst for the decomposition of hydrogen peroxide into water and oxygen. Hydrogen ions are reduced to hydrogen gas during the corrosion of iron, and the result is an increase in $\mathrm{pH}$. At higher $\mathrm{pH}$ ferric iron is less soluble, accounting for the precipitation of hematite (ferric oxide).

The zirconium-hafnium alloy (\#1) also performed well, as would be expected considering the low solubility of both metals at the $\mathrm{pH}$ used, even allowing for the complexing effect of oxalate on zirconium. ${ }^{31}$ Considering that this sample was tested in the batch of solution without the formic acid addition, its solution maintained its $\mathrm{pH}$ even better than the control in this batch (\#5).

The remaining ceramic samples (\#14, 18, 16, 17, and 13) had little impact on their solutions and showed little or no weight loss, with the exception of \#13, 
zirconolite. Its small weight loss was probably due to dissolution of residual starting material that remained unreacted during hot pressing. The elevated oxalate concentration value is within the measurement uncertainty, which was high for this particular sample, and is not considered significant.

Boron carbide is known to be difficult to dissolve. According to Samsonov et al.," 32 "Boron carbide is stable with respect to acids....mineral acids, taken individually, practically do not decompose it under normal conditions. For example, nitric acid oxidizes boron carbide only at relatively high temperatures and under the condition of a continuous return to the reaction mixture of the oxides of nitrogen that are volatilized upon heating." Gmelin ${ }^{33}$ reports that " $\mathrm{B}_{4} \mathrm{C}$ is stable in the cold against the acids $\mathrm{HCl}, \mathrm{H}_{2} \mathrm{SO}_{4}, \mathrm{HNO}_{3}, \mathrm{HF}$, and $\mathrm{HClO}_{4}$ and their mixtures, and fairly stable when hot. Only in $1: 1$ diluted acids does $\mathrm{B}_{4} \mathrm{C}$ show a very slight solubility." Boron carbide has been known to dissolve under neutron and gamma irradiation in reactor cooling water at about $350^{\circ} \mathrm{C}$ when it has been exposed as a result of failure of control rod cladding. ${ }^{20}$ This observed dissolution is consistent with what is known about boron carbide and the effects of irradiation. First of all, boron carbide is thermodynamically very unstable with respect to reaction with oxygen to form boron oxide and carbon dioxide. The free energy of the oxidation reaction is $-2,715 \mathrm{~kJ} / \mathrm{mole}$ at $25^{\circ} \mathrm{C} .^{17}$ Second, neutrons produce ( $\mathrm{n}$, alpha) reactions which cause atomic displacements in boron carbide that increase the kinetics of transformation. Third, radiolysis of water produces oxidizing conditions, and fourth, boron oxide is soluble in water.

Given its high starting mass, the hafnium oxide sample showed negligible weight change. Also, only $0.09 \mathrm{ppm}$ of $\mathrm{Hf}$ was found in the solution. This is consistent with its very low solubility ${ }^{34}$. The monazite and zircon samples showed barely detectable weight changes. The silicon observed in the solution used with the zircon sample (\#17) may have come from the Pyrex vessel or from unreacted $\mathrm{SiO}_{2}$ in the sample.

No special efforts were made to produce high quality ceramics for this scoping study. Of the ceramics fabricated by us (hafnium oxide, gadolinium monazite, zircon, and zirconolite), the first two were most readily formed from the pure oxides by hot pressing. Zircon would better be made by pre-reacting before hot pressing. Making high-quality single-phase zirconolite requires intimate mixing of starting materials on a very fine scale. The excellent performance of these materials in spite of incompletely reacted samples demonstrates their high chemical durability. 


\section{Summary and Conclusions}

1. The desirable properties for waste package basket materials are reasonable strength, high thermal conductivity, high neutron absorption capability, easy fabricability, good corrosion resistance, and low cost. Of these properties, superior corrosion resistance is uniquely important for long-term criticality control in a geologic repository.

2. Radiolysis of air and vadose water in a failed waste package over a long period of time could produce significant quantities of several acids and hydrogen peroxide.

3. Short-term scoping corrosion tests of a variety of candidate materials in a solution containing these substances at $90^{\circ} \mathrm{C}$ showed that both aluminumand copper-based materials are vulnerable to significant corrosion under these conditions, as expected.

4. Boron-containing stainless steel-based materials performed well in the absence of welds. The single welded sample tested underwent significant corrosion. Other welded boron-containing stainless steels or the same material welded by a different process or heat treated differently may not show vulnerability to corrosion. Further testing will be required if designs call for welding these materials.

5. Zirconium-hafnium alloy performed well in the test medium used, as expected.

6. Ceramics, including boron carbide, hafnium oxide, gadolinium monazite, zircon (containing hafnium), and zirconolite (containing hafnium) all performed well, even though the samples of the latter two materials were not fully reacted from the pure oxides during their fabrication.

7. The most reliable protection against loss of neutron absorber from waste packages over the long term in a geologic repository is low solubility of the absorber element used, under the conditions expected. Using this criterion, hafnium is superior to both gadolinium and boron. ${ }^{33}$

8. If boron is to be used as the neutron absorber, it would be preferable to use it in the form of boron carbide or in high-chromium metal borides that are surrounded by a corrosion resistant metal. Boron carbide is thermodynamically very unstable with respect to reaction with oxygen to produce boron oxide and carbon dioxide. Boron oxide is soluble in water, and dissolution of boron carbide has been found to occur in neutron- and gamma-irradiated reactor cooling water at temperatures near $350^{\circ} \mathrm{C}$. The rate of dissolution under repository conditions is expected to be low, but cannot be quantified at present. Non-chromium metal borides are generally soluble in acid solutions, but higher chromium borides have been found to be resistant to attack. 
9. Future efforts will be directed toward developing a better understanding of the long-term corrosion behavior of boron carbide and boron-containing stainless steels under the expected range of conditions since these materials are deemed most cost-effective by the Waste Package Development Department of the Management and Operating Contractor.

\section{Acknowledgments}

Sample materials were supplied by the following representatives and their firms: Marvin Wachs (Eagle-Picher Industries), Robin Carden (Alyn Corporation), Bruce R. Jansen (AAR Advanced Structures), Jack D. Troxell and Thomas M. Murphy (SCM Metal Products, with Copper Development Association), John Leonard (Bohler Bleche Sheet and Plate), Greg Del Corso (Carpenter Technology) and Douglas Brenizer (Teledyne Wah Chang Albany). Richard Landingham of LLNL supplied the $A \cdot B$ ceramic and the $B_{4} C$. Metallography was performed by Edward Sedillo. Ceramography was performed by James Furr. Dominic del Guidice did the x-ray diffraction analysis. James Yoshiyama performed SEM-EDS analysis on ceramic samples. Terry Duewer, Nora Butler-Briant, and Richard Torres performed chemical analysis on solutions. David Stahl of Framatome Cogema Fuel Company, part of the Civilian Radioactive Waste Management and Operating Contractor organization, and R. Daniel McCright of LLNL provided technical and management oversight. Helpful discussions were had with John Massari of Framatome Cogema, Henry Loo and Ron Mizia of Lockheed Idaho, and Paul Singh of Holtec International. Nan Poggio typed the draft version of this report. The authors are grateful for all these contributions. This work was performed as part of the Yucca Mountain Site Characterization Project under the direction of the U.S. Department of Energy Office of Civilian Radioactive Waste Management, by Lawrence Livermore National Laboratory under Contract No. W-7405-Eng-48.

\section{References}

1. Van Konynenburg, R.A., McCright, R.D., Roy, A.K., and Jones, D.A., "Engineered Materials Characterization Report," UCRL-ID-119564, Lawrence Livermore National Laboratory, Livermore, CA 94550 (December 1994).

2. TRW Environmental Safety Systems, Inc., "Multi-Purpose Canister (MPC) Implementation Program Conceptual Design Phase Report, Vol. IIA-MPC Conceptual Design Report, Doc. No. A20000000-00811-5705-00002, Rev. 00, TRW, Vienna, VA (September 1994).

3. TRW Environmental Safety Systems, Inc., "Initial Summary Report for Repository/Waste Package Advanced Conceptual Design," Doc. No. B00000000-01717-5705-00015, Rev. 00, TRW, Vienna, VA (August 1994). 
4. Van Konynenburg, R.A., "Waste Package Basket Materials, Scientific Investigation Plan," SIP-CM-02, Lawrence Livermore National Laboratory Yucca Mountain Project, Livermore, CA (March, 1995).

5. TRW Environmental Safety Systems, Inc., "Controlled Design Assumption Document (CDA)," Doc. No. B00000000-01717-4600-00032 Rev. 00A, TRW, Las Vegas, NV (June, 1994).

6. U. S. Nuclear Regulatory Commission, Final rule, federal regulation 10 CFR Part 60, Code of Federal Regulations, U.S. Government Printing Office, Washington, D. C. (1995).

7. Lederer, C. M., and Shirley, V. S., Table of Isotopes, Seventh Ed., John Wiley and Sons, New York (1978).

8. National Research Council, "Ground Water at Yucca Mountain: How High Can It Rise?," National Academy Press, Washington, D.C. (1992).

9. Harrar, J.E., Carley, J.F., Isherwood, W. F., and Raber, E., "Report of the Committee to Review the Use of $\mathrm{J}-13$ Well Water in Nevada Nuclear Waste Storage Investigations," UCID-21867, Lawrence Livermore National Laboratory, Livermore, CA (January, 1990).

10. Johnson, A.B., Jr. and Gilbert, E.R., "Technical Basis for Storage of ZircaloyClad Spent Fuel in Inert Gases," PNL-4835, Battelle Pacific Northwest Laboratories, Richland, WA (1983).

11. Lundgren, K., "Radiation Levels and Absorbed Doses Around Copper Canisters Containing Spent LWR Fuel," SKBF KBS Technical Report No. 82-11, SKB, Stockholm, Sweden (1982).

12. Christensen, H., and Bjergbakke, E., "Radiolysis of Ground Water from Spent Fuel," SKBF KBS Technical Report No. 82-18, SKB, Stockholm, Sweden (1982).

13. Reed, D. T., "Progress in Assessing the Effect of lonizing Radiation on the Anticipated Waste Package Environment at the Yucca Mountain Potential Repository Site," Proceedings of Nuclear Waste Packaging, Focus '91, American Nuclear Society, La Grange Park, IL (1991).

14. Van Konynenburg, R. A., "Radiation Chemical Effects in Experiments to Study the Reaction of Glass in an Environment of Gamma-Irradiated Air, Groundwater, and Tuff", UCRL-53719, Lawrence Livermore National Laboratory, Livermore, CA (May 1986).

15. Barkatt, Aaron, Barkatt, Alisa, and Sousanpour, W., "Gamma Radiolysis of Aqueous Media and Its Effects on the Leaching Processes of Nuclear Waste Disposal Materials," Nucl. Technol. 60, 218 (1983). 
16. Skoog, Douglas A. and West, Donald M., Analytical Chemistry, 3rd edition, Saunders College, Philadelphia (1979).

17. Dean, J.A., Ed., Lange's Handbook of Chemistry, Thirteenth Ed., McGrawHill, New York, (1985).

18. Tipton, C.R., Jr., Ed., Reactor Handbook, Vol. 1. Materials, Second Edition, Interscience Publishers, New York (1960).

19. Ursu, I., Physics and Technology of Nuclear Materials, Pergamon Press, New York (1985).

20. Gupta, C. K., Materials in Nuclear Energy Applications, Vol. II, CRC Press, Boca Raton, FL (1989).

21. Nuclear Waste Policy Act of 1982, Pub. Law 97-425, 96 Stat. 2201, codified at 42 U.S.C. 10101 et seq.

22. American Society for Testing and Materials, "G1-90, Standard Practice for Preparing, Cleaning, and Evaluating Corrosion Test Specimens," Annual Book of ASTM Standards, ASTM, Philadelphia, PA (1995).

23. Van Konynenburg, R.A., "Corrosion Considerations in Choosing MPC Basket Materials," unpublished white paper dated December 7, 1994, Lawrence Livermore National Laboratory, Livermore, CA.

24. Massalski, T.B., Binary Alloy Phase Diagrams, Second Edition, Vol. 1, p. 123, ASM International, Metals Park, OH (1990).

25. Personal communication with Marvin Wachs, Eagle-Picher Industries (August 24, 1995).

26. Trotman-Dickenson, A.F., Exec. Ed., Comprehensive Inorganic Chemistry, Vol. 1, pp. 727-8, Pergamon Press, New York (1973).

27. Personal communication with Bruce Jansen, AAR Advanced Structures (August 23, 1995).

28. Personal communication with Robin Carden, Alyn Corp. (August 23, 1995).

29. Uhlig, H.H., and Revie, R.W., Corrosion and Corrosion Control, Third Ed., John Wiley and Sons, New York (1985).

30. Robino, C.V., and Cieslak, M.J., "High-Temperature Metallurgy of Advanced Borated Stainless Steels," Met. and Mat. Trans. A, 26A, 1673-1685 (1995).

31. Cotton, F.A., and Wilkinson, G., Advanced Inorganic Chemistry, Fifth Ed., John Wiley and Sons, New York (1988). 
32. Samsonov, G.V., Markovskii, L.Ya., Zhigach, A.F., and Valyashko, M.G., "Boron, Its Compounds and Alloys", AEC-tr-5032 (Book 1) U. S. Atomic Energy Commission, Washington, DC (1960), transiated from a publication of the Publishing House of the Academy of Sciences of the Ukranian S.S.R., Kiev (1960).

33. Amberger, E. and Stumpf, W., "Boron, Supplemental Volume 2: Elemental Boron and Boron Carbides," Gmelin Handbook of Inorganic Chemistry, K. Buschbeck, Ed., Springer-Verlag, Berlin (1981), p. 189.

34. Pourbaix, M., Atlas of Electrochemical Equilibria in Aqueous Solutions. Pergamon Press, New York (1966). 


\section{Appendix A : Detailed Description of Samples Tested}

Table A-1

Material and Supplier Information for Samples Tested

\begin{tabular}{|c|c|c|c|}
\hline $\begin{array}{l}\text { Sample } \\
\text { Number }\end{array}$ & Material & Supplier & $\begin{array}{c}\text { Mass } \\
(\mathrm{g})\end{array}$ \\
\hline 2 & $\begin{array}{l}\text { Boron Aluminum: rolled } 1100 \\
\text { alloy from } 94-130 \text { Lot } 2 ; 4.3 \\
\text { wt.\% }{ }^{10} \mathrm{~B} \text { min., dispersed } \mathrm{AlB}_{2} \\
\text { particles with area density } \\
0.010 \mathrm{~g}{ }^{10} \mathrm{~B} / \mathrm{cm}^{2} \text { min. }\end{array}$ & Eagle-Picher & 1.611 \\
\hline 8 & $\begin{array}{l}\text { Boron Aluminum: rolled } 6061 \\
\text { alloy from 94-100 Part } \\
3128722 \mathrm{~T} \text { marked "10"; } 0.6 \\
\text { wt.\% }{ }^{10} \mathrm{~B} \text { min., dispersed } \mathrm{AlB}_{2} \\
\text { particles with area density } \\
0.019 \mathrm{~g}{ }^{10} \mathrm{~B} / \mathrm{cm}^{2} \text { min. }\end{array}$ & Eagle-Picher & 8.388 \\
\hline 9 & $\begin{array}{l}\text { Boron Aluminum: extruded } \\
6351 \text { alloy from } 94-128 \text { Part } \\
213304 \text { marked "7"; } 0.5 \text { wt. } \% \\
{ }^{10} \mathrm{~B} \text { min., dispersed } \mathrm{AlB}_{2} \\
\text { particles with area density } \\
0.0064 \mathrm{~g}^{10} \mathrm{~B} / \mathrm{cm}^{2} \text { min. }\end{array}$ & Eagle-Picher & 5.072 \\
\hline 7 & $\begin{array}{l}\text { Boralyn: extruded } 6061 \\
\text { aluminum alloy, F-cond. } \\
\text { bicycle chain stay, } 1 \text { atom \% } \\
\text { B4Cp as dispersed, coated 5- } \\
\mu \mathrm{m} \text { particles }\end{array}$ & Alyn Corp. & 5.404 \\
\hline 3 & $\begin{array}{l}\text { Boral: hot-rolled composite } \\
\text { plate with core of mixed } \\
\text { aluminum and } \mathrm{B}_{4} \mathrm{C} \text { powders, } \\
\text { with } 1100 \text { aluminum alloy } \\
\text { cladding; from } \mathrm{SN} \text { OB310346- } \\
1-9\end{array}$ & AAR Advanced Structures & 2.370 \\
\hline 29 & $\begin{array}{l}\text { Anodized Boral: Type 1-Class } \\
1 \text { anodized in chromic acid }\end{array}$ & AAR Advanced Structures & 3.287 \\
\hline 30 & $\begin{array}{l}\text { Anodized Boral: Type 1-Class } \\
1 \text { anodized in chromic acid } \\
\text { intentionally scratched with } \\
\text { diamond scribe }\end{array}$ & AAR Advanced Structures & 3.538 \\
\hline 31 & $\begin{array}{l}\text { Anodized Boral: Type 2-Class } \\
1 \text { anodized in sulfuric acid }\end{array}$ & AAR Advanced Structures & 3.463 \\
\hline
\end{tabular}


Table A-1(Continued)

Material and Supplier Information for Samples Tested

\begin{tabular}{|c|c|c|c|}
\hline $\begin{array}{l}\text { Sample } \\
\text { Number } \\
\end{array}$ & Material & Supplier & $\begin{array}{c}\text { Mass } \\
(\mathrm{g}) \\
\end{array}$ \\
\hline 33 & $\begin{array}{l}\text { Anodized Boral: Type 2-Class } \\
1 \text { anodized in sulfuric acid } \\
\text { intentionally scratched with } \\
\text { diamond scribe }\end{array}$ & AAR Advanced Structures & 3.448 \\
\hline 34 & $\begin{array}{l}\text { Anodized Boral: Type 3-Class } \\
2 \text { anodized in sulfuric acid }\end{array}$ & AAR Advanced Structures & 3.423 \\
\hline 36 & $\begin{array}{l}\text { Anodized Boral: Type 3-Class } \\
2 \text { anodized in sulfuric acid } \\
\text { intentionally scratched with } \\
\text { diamond scribe }\end{array}$ & AAR Advanced Structures & 3.409 \\
\hline 23 & $\begin{array}{l}\mathrm{A} \bullet \mathrm{B}: 50 \text { wt. } \% \mathrm{Al}_{2} \mathrm{O}_{3}, 50 \text { wt. } \% \\
\mathrm{~B}_{4} \mathrm{C} \text {, hot-pressed }\end{array}$ & $\begin{array}{l}\text { R. Landingham } \\
\text { LLNL }\end{array}$ & 9.564 \\
\hline 24 & $\begin{array}{l}\text { Copper }+1.5 \text { wt. } \% \text { Boron: } \\
\text { extruded, rod 4B, copper with } \\
\text { dispersed boron particles }\end{array}$ & $\begin{array}{l}\text { SCM Metal Products and } \\
\text { Copper Devel. Assoc. }\end{array}$ & 22.978 \\
\hline 25 & $\begin{array}{l}\text { Glidcop Al-15+1.5 wt. \% B: } \\
\text { extruded, Cu core, dispersion } \\
\text { strengthened with } 0.3 \text { wt. \% } \\
\mathrm{Al}_{2} \mathrm{O}_{3} \text { incorporating dispersed } \\
\text { boron particles, with } \mathrm{Cu} \\
\text { cladding }\end{array}$ & $\begin{array}{l}\text { SCM Metal Products and } \\
\text { Copper Devel. Assoc. }\end{array}$ & 28.240 \\
\hline 4 & $\begin{array}{l}\text { Copper }+1.8 \text { wt. } \% \text { } \mathrm{B}_{4} \mathrm{C}: \\
\text { extruded, } \mathrm{Cu} \text { with dispersed } \\
\mathrm{B}_{4} \mathrm{C} \text { particles }\end{array}$ & $\begin{array}{l}\text { SCM Metal Products and } \\
\text { Copper Devel. Assoc. }\end{array}$ & 6.767 \\
\hline 10 & $\begin{array}{l}\text { Glidcop Al-15 }+1.8 \text { wt. } \% \mathrm{~B}_{4} \mathrm{C} \text { : } \\
\text { extruded, Cu core, dispersion } \\
\text { strengthened with } 0.3 \text { wt. \% } \\
\mathrm{Al}_{2} \mathrm{O}_{3} \text { incorporating dispersed } \\
\text { boron particles, Cu clad }\end{array}$ & $\begin{array}{l}\text { SCM Metal Products and } \\
\text { Copper Devel. Assoc. }\end{array}$ & 5.185 \\
\hline 20 & $\begin{array}{l}\text { Type } 304 \mathrm{~L} \text { austenitic stainless } \\
\text { steel (control sample) }\end{array}$ & Metal Samples, Inc. & 14.659 \\
\hline 26 & 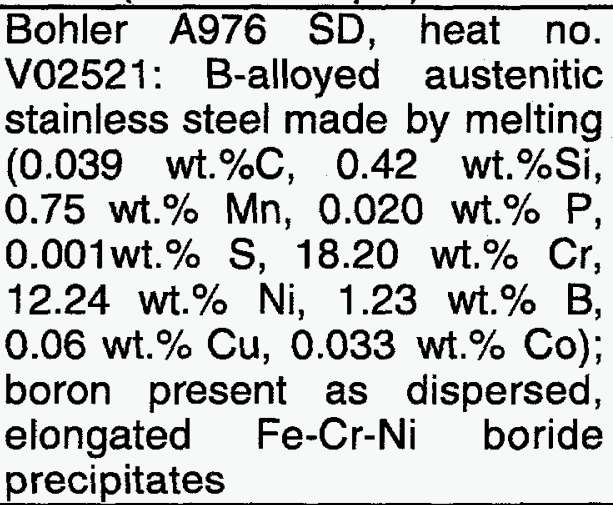 & AAR Advanced Structures & 17.261 \\
\hline
\end{tabular}


Table A-1(Continued)

Material and Supplier Information for Samples Tested

\begin{tabular}{|c|c|c|c|}
\hline $\begin{array}{l}\text { Sample } \\
\text { Number }\end{array}$ & Material & Supplier & $\begin{array}{l}\text { Mass } \\
(\mathrm{g})\end{array}$ \\
\hline 22 & $\begin{array}{l}\text { Neutrosorb Plus: B-alloyed } \\
\text { austenitic stainless steel made } \\
\text { by powder process, base metal } \\
\text { (0.08 wt.\% max. C, } 2.00 \text { wt. } \% \\
\text { min. Mn, } 0.75 \text { wt. } \% \text { max. Si, } \\
18-20 \text { wt. } \% \mathrm{Cr}, 12-15 \text { wt. } \% \mathrm{Ni} \text {, } 15 \\
0.045 \text { wt. } \% \text { max. } \mathrm{P}, 0.030 \text { wt.\% } \\
\text { max. S, } 1.75 \text { wt. } \% \text { B } 0.110 \\
\text { wt. } \% \text { max. N), boron present as } \\
\text { dispersed, near-spherical } \\
\text { boride particles }\end{array}$ & Carpenter Technoloty & 8.055 \\
\hline 19 & $\begin{array}{l}\text { Neutrosorb PLUS: B-alloyed } \\
\text { austenitic stainless steel made } \\
\text { by powder process, welded } \\
\text { sample, same material as } \\
\text { sample } 22\end{array}$ & Carpenter Technoloty & 12.918 \\
\hline 1 & $\begin{array}{l}\text { Zircadyne: ASTM Grade } \\
\text { R60702 unalloyed zirconium } \\
(99.2 \text { wt.\% min. } \mathrm{Zr}+\mathrm{Hf}, 4.5 \text { wt.\% } \\
\text { max. Hf, } 0.20 \text { wt.\% max. } \mathrm{Fe}+\mathrm{Cr} \text {, } \\
0.005 \text { wt.\% max. H, } 0.025 \text { wt.\% } \\
\text { max. } \mathrm{N}, 0.05 \text { wt.\% max. } \mathrm{C}, 0.16 \\
\text { wt.\% max. O) }\end{array}$ & $\begin{array}{c}\text { Teledyne Wah Chang, } \\
\text { Albany }\end{array}$ & 3.463 \\
\hline 14 & Boron carbide: hot pressed & $\begin{array}{l}\text { R. Landingham } \\
\text { LLNL }\end{array}$ & 2.028 \\
\hline 18 & $\begin{array}{l}\text { Hafnium oxide- } 5 \text { wt. } \% \text { yttrium } \\
\text { oxide, yttrium oxide present to } \\
\text { stabilize high-temp. tetragonal } \\
\text { crystal structure of } \mathrm{HfO}_{2}\end{array}$ & hot pressed by P. Curtis & 10.460 \\
\hline 16 & $\begin{array}{l}\text { Gadolinium phosphate: } \\
\text { pressed monazite analog }\end{array}$ & hot pressed by P. Curtis & 0.838 \\
\hline 17 & $\begin{array}{l}\text { Zirconium silicate (zircon) } \\
\text { containing } 5 \text { wt.\% } \mathrm{HfO}_{2}: \text { hot } \\
\text { pressed, contains some } \\
\text { unreacted } \mathrm{ZrO}_{2}, \mathrm{SiO}_{2} \text { and } \mathrm{HfO}_{2}\end{array}$ & hot pressed by P. Curtis & 4.231 \\
\hline 13 & $\begin{array}{l}\text { Calcium zirconium titanate } \\
\text { (zirconolite) containing } 5 \text { wt.\% } \\
\mathrm{HfO}_{2} \text {, contains some unreacted } \\
\mathrm{ZrO}_{2}, \mathrm{SiO}_{2} \text { and } \mathrm{HfO}_{2}\end{array}$ & hot pressed by $P$. Curtis & 3.800 \\
\hline
\end{tabular}


Table A-2

Measured and Reported Densities for Samples Tested

\begin{tabular}{|c|c|c|c|c|}
\hline $\begin{array}{l}\text { Sample } \\
\text { Number }\end{array}$ & $\begin{array}{c}\text { Shape and } \\
\text { Dimensions }(\mathrm{cm})\end{array}$ & $\begin{array}{l}\text { Calculated } \\
\text { Volume }\left(\mathrm{cm}^{3}\right)\end{array}$ & $\begin{array}{l}\text { Calculated } \\
\text { Density } \\
\left(\mathrm{g} / \mathrm{cm}^{3}\right)\end{array}$ & $\begin{array}{l}\text { Specified or } \\
\text { Theoretical } \\
\text { Maximum } \\
\text { Density } \\
\left(\mathrm{g} / \mathrm{cm}^{3}\right)\end{array}$ \\
\hline 2 & $\begin{array}{c}\text { rectangular bar } \\
3.85 \times 1.50 \times 0.102\end{array}$ & 0.589 & 2.73 & 2.7 \\
\hline 8 & $\begin{array}{c}\text { rectangular bar } \\
4.41 \times 1.24 \times 0.567\end{array}$ & 3.10 & 2.71 & 2.7 \\
\hline 9 & $\begin{array}{c}\text { rectangular bar } \\
2.51 \times 1.46 \times 0.508\end{array}$ & 1.86 & 2.72 & 2.7 \\
\hline 7 & $\begin{array}{c}\text { Tube } \\
2.21 \mathrm{~L}, 2.04 \mathrm{OD}, \\
1.73 \mathrm{ID}\end{array}$ & 2.03 & 2.66 & 2.69 \\
\hline 3 & $\begin{array}{c}\text { rectangular plate } \\
3.32 \times 1.44 \times 0.203\end{array}$ & 0.971 & 2.44 & $2.48-2.71$ \\
\hline 29 & $\begin{array}{l}\text { rectangular plate } \\
2.59 \times 2.47 \times 0.22\end{array}$ & 1.41 & 2.34 & $2.48-2.71$ \\
\hline 30 & $\begin{array}{l}\text { rectangular plate } \\
2.60 \times 2.55 \times 0.22 \\
\end{array}$ & 1.46 & 2.43 & $2.48-2.71$ \\
\hline 31 & $\begin{array}{l}\text { rectangular plate } \\
2.60 \times 2.50 \times 0.23\end{array}$ & 1.47 & 2.35 & $2.48-2.71$ \\
\hline 33 & $\begin{array}{l}\text { rectangular plate } \\
2.25 \times 2.47 \times 0.23\end{array}$ & 1.30 & 2.65 & $2.48-2.71$ \\
\hline 34 & $\begin{array}{c}\text { rectangular plate } \\
2.55 \times 0.22 \\
\text { width estimated } 2.5\end{array}$ & 1.40 & 2.44 & $2.48-2.71$ \\
\hline 36 & $\begin{array}{c}\text { rectangular plate } \\
2.54 \times 2.44 \times 0.22\end{array}$ & 1.36 & 2.50 & $2.48-2.71$ \\
\hline 23 & $\begin{array}{l}\text { octagonal cylinder } \\
1.27 \mathrm{D} \text { (flats) } \times 2.17 \mathrm{~L}\end{array}$ & 2.90 & 3.30 & 3.24 \\
\hline 24 & $\begin{array}{c}\text { circular cylinder } \\
1.14 \mathrm{D} \times 2.64 \mathrm{~L}\end{array}$ & 2.69 & 8.53 & 8.98 \\
\hline 25 & $\begin{array}{c}\text { circular cylinder } \\
1.27 \mathrm{D} \times 2.62 \mathrm{~L}\end{array}$ & 3.32 & 8.51 & 8.92 \\
\hline 4 & $\begin{array}{c}\text { rectangular bar } \\
3.19 \times 1.02 \times 0.248\end{array}$ & 0.807 & 8.39 & 8.57 \\
\hline 10 & $\begin{array}{c}\text { rectangular bar } \\
2.67 \times 1.03 \times 0.229\end{array}$ & 0.630 & 8.23 & 8.52 \\
\hline 20 & $\begin{array}{c}\text { plate } \\
5.10 \times 2.54 \times 0.147 \\
\text { (with one } 0.6350 \\
\text { hole) }\end{array}$ & 1.86 & 7.89 & 7.93 \\
\hline 26 & $\begin{array}{c}\text { plate } \\
5.09 \times 2.74 \times 0.152\end{array}$ & 2.12 & 8.14 & 7.73 \\
\hline
\end{tabular}


Table A-2 (Continued)

Measured and Reported Densities for Samples Tested

\begin{tabular}{|c|c|c|c|c|}
\hline $\begin{array}{c}\text { Sample } \\
\text { Number }\end{array}$ & $\begin{array}{c}\text { Shape and } \\
\text { Dimensions }(\mathrm{cm})\end{array}$ & $\begin{array}{c}\text { Calculated } \\
\text { Volume }\left(\mathrm{cm}^{3}\right)\end{array}$ & $\begin{array}{c}\text { Calculated } \\
\text { Density } \\
\left(\mathrm{g} / \mathrm{cm}^{3}\right)\end{array}$ & $\begin{array}{c}\text { Specified or } \\
\text { Theoretical } \\
\text { Maximum } \\
\text { Density } \\
\left(\mathrm{g} / \mathrm{cm}^{3}\right)\end{array}$ \\
\hline 22 & $\begin{array}{c}\text { rectangular bar } \\
5.54 \times 0.927 \times \\
0.203\end{array}$ & 1.04 & 7.73 & 7.76 \\
\hline 19 & $\begin{array}{c}\text { rectangular bar } \\
4.00 \times 2.08 \times 0.203\end{array}$ & 1.69 & 7.65 & 7.76 \\
\hline 1 & $\begin{array}{c}\text { rectangular bar } \\
4.90 \times 0.604 \times \\
0.196\end{array}$ & 0.580 & 5.97 & 6.51 \\
\hline 14 & $\begin{array}{c}\text { rectangular block } \\
1.65 \times 1.65 \times 0.343\end{array}$ & 0.934 & 2.17 & 2.52 \\
\hline 18 & $\begin{array}{c}\text { circular cylinder } \\
1.09 \mathrm{D} \times 1.17 \mathrm{~L}\end{array}$ & 1.092 & 9.58 & 9.68 \\
\hline 16 & $\begin{array}{c}\text { circular cylinder } \\
1.09 \mathrm{D} \times 0.160 \mathrm{~L}\end{array}$ & 0.149 & 5.61 & 5.99 \\
\hline 17 & $\begin{array}{c}\text { circular cylinder } \\
1.09 \mathrm{D} \times 1.05 \mathrm{~L}\end{array}$ & 0.980 & 4.32 & 4.56 \\
\hline 13 & $\begin{array}{c}\text { circular cylinder } \\
1.09 \mathrm{D} \times 1.03 \mathrm{~L}\end{array}$ & 0.961 & 3.95 & 4.44 \\
\hline
\end{tabular}

